\title{
The Effect of Climate Change-Induced Temperature Increase on Performance and Environmental Impact of Intensive Pig Production Systems
}

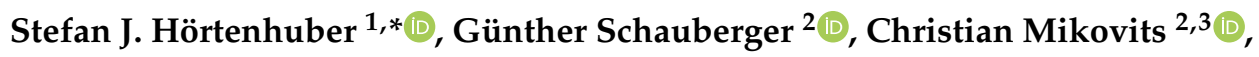 \\ Martin Schönhart ${ }^{3}{ }^{\circledR}$, Johannes Baumgartner ${ }^{4}$, Knut Niebuhr ${ }^{4,+}$, Martin Piringer ${ }^{5}{ }^{\circledR}$, \\ Ivonne Anders ${ }^{6}$, Konrad Andre ${ }^{6}$, Isabel Hennig-Pauka ${ }^{7,8}{ }^{\circ}$ and Werner Zollitsch ${ }^{1}$ \\ 1 Division of Livestock Sciences, Department of Sustainable Agricultural Systems, \\ University of Natural Resources and Life Sciences Vienna, Gregor Mendel-Straße 33, 1180 Vienna, Austria; \\ werner.zollitsch@boku.ac.at \\ 2 WG Environmental Health, Unit for Physiology and Biophysics, University of Veterinary Medicine, \\ 1210 Vienna, Austria; gunther.schauberger@vetmeduni.ac.at (G.S.); christian.mikovits@boku.ac.at (C.M.) \\ 3 Institute for Sustainable Economic Development, Department of Economics and Social Sciences, \\ University of Natural Resources and Life Sciences, 1180 Vienna, Austria; martin.schoenhart@boku.ac.at \\ 4 Institute of Animal Husbandry and Animal Welfare, University of Veterinary Medicine, 1210 Vienna, \\ Austria; johannes.baumgartner@vetmeduni.ac.at (J.B.); Knut.Niebuhr@vetmeduni.ac.at (K.N.) \\ 5 Department of Environmental Meteorology, Central Institute of Meteorology and Geodynamics, \\ 1190 Vienna, Austria; martin.piringer@zamg.ac.at \\ 6 Department for Climate Research, Central Institute of Meteorology and Geodynamics, 1190 Vienna, Austria; \\ ivonne.anders@zamg.ac.at (I.A.); konrad.andre@zamg.ac.at (K.A.) \\ 7 Field Station for Epidemiology, University of Veterinary Medicine Hannover, 49456 Bakum, Germany; \\ isabel.hennig-pauka@tiho-hannover.de \\ 8 University Clinics for Swine, Department for Farm Animals and Veterinary Public Health, \\ University of Veterinary Medicine, 1190 Vienna, Austria \\ * Correspondence: stefan.hoertenhuber@boku.ac.at \\ + Dedicated to our colleague, Knut Niebuhr, who passed away before the manuscript was submitted.
}

Received: 9 October 2020; Accepted: 11 November 2020; Published: 13 November 2020

\begin{abstract}
This study examined climate change impacts (CCI) on productivity of pig production systems, their resource use, environmental impacts and the relevance of potential adaptation options. The impact of increasing temperature and temperature-humidity index (THI) on performance of pigs in confined housing systems was analysed by a meta-analysis. Using climate data for an Austrian site for the period 1981 to 2010, different scenarios (cold year, warm year, hot year, worst case scenario) were modelled and compared. Although significant differences between thermoneutral and heat stress conditions were detected for the analysed traits of growing and finishing pigs, overall performance, resource use (cumulative energy demand) and environmental impacts (global warming, acidification and eutrophication potential) per kg of live mass for finished pigs and reared piglets did not significantly differ between most scenarios. Elements of pig production systems resilient to $\mathrm{CCI}$, which were not considered under performance and environmental impacts (LCA), were addressed in a system analysis that was based on literature and expert knowledge. The most important detected system elements are plants and animals with an appropriate genetic potential, securing the access to inexpensive feed, including land for feed production, securing water supply and the implementation of health plans and measures against diseases associated with CCI.
\end{abstract}

Keywords: livestock; heat stress; indoor climate; climate change impacts; global warming potential; GWP; eutrophication potential; acidification potential; cumulative energy demand 


\section{Introduction}

Anthropogenic greenhouse gas (GHG) emissions are the major driver of climate change [1]. Food supply accounts for $19 \%$ to $29 \%$ of global GHG emissions, the vast majority of it coming from the agricultural sector [2]. The livestock sector contributes $15 \%$ of global anthropogenic GHG emissions, with pigs accounting for $9 \%$ of all livestock-related emissions [3]. At the same time, climate change threatens global food security and affects livestock production, for instance, through effects on feed production, through livestock diseases or heat stress [4]. Global temperature has already increased by $0.61^{\circ} \mathrm{C}$ (with a $95 \%$ confidence interval of 0.55 to $0.67^{\circ} \mathrm{C}$ ) as compared to the pre-industrial period. Until 2100 , global temperatures are expected to increase by about $1.5^{\circ} \mathrm{C}\left(0.75-2.2^{\circ} \mathrm{C}\right)$ for a low-emission scenario (emission mitigation) and up to above $4.5^{\circ} \mathrm{C}\left(3.4-5.8^{\circ} \mathrm{C}\right)$ for a high-emission scenario [1]. This will result in more frequent heat stress situations, especially during the summer months.

Commercial, highly productive livestock systems in temperate zones mainly use confined livestock housing systems for pigs [5]. This entails advantages in terms of the control of thermal environment, i.e., maintaining temperature within a specific range, e.g., by controlling the ventilation rate. Typical ventilation systems in livestock buildings control temperatures by variable air volume flows. However, during the summer months, their capacity is limited. In this regard, the question arises whether cooling systems involving an air treatment will become necessary for pig houses in temperate zones due to climate change in order to maintain livestock performance, including economic performance, and ecological impact at acceptable levels [6].

In the past, animal genetics have been modified by breeding in order to increase output. Selection for primary performance traits have put several mechanisms of physiological regulation under pressure. This contributes, among other factors, to a specific vulnerability to heat stress in situations with high ambient temperatures [7]. High performing livestock have to cope with high metabolic heat production due to increased metabolic rates. The occurrence of high ambient temperatures, increased frequency of diseases and increasing mortality following immunosuppression or increasing pathogen pressure, may result in negative effects on fertility and other performance traits, such as growth rate of pigs $[8,9]$.

Physiological mechanisms that lead to reduced performance include, among others, a reduced feed intake [10] and a higher (maintenance) energy requirement due to thermoregulation [11]. In the case of prolonged heat stress, there is a general change in the hormone status and the metabolic rate [10]. When a decline in the adaptive thermoregulatory mechanisms becomes apparent, reduced well-being occurs [12]. Below and above a certain temperature range, animals are no longer able to maintain their core temperature on a constant level, and hypothermia and hyperthermia, respectively, will occur. The critical upper limit for the body core temperature is about $42-45^{\circ} \mathrm{C}$ [13]. The limits of the thermoneutral zone (TNZ) for pigs depend on body mass and the age of the animals and vary widely in the literature. It has to be noted that these temperature values are not independent from the coinciding humidity values, which are considered together with the temperature in a temperature humidity index (THI). The majority of publications reviewed by Escarcha et al. [14] (71\%) dealt with climate change impacts (CCI) on ruminants. Monogastric livestock, particularly pigs and chickens, seem to receive less attention in the scientific literature, although their health and productivity may be even more affected by CCI [10].

So far, considerations on the adaptation of livestock production systems (PS) to CCI mostly focused on policy advice (national and international climate research panels) or were limited to the technical adjustment of housing systems [15]. No system analysis assessing the sensitivity to CCI specifically for pig production systems was identified in the literature, which takes into account the multiple relationships between the various elements of a PS.

Quantitative analyses of global warming on production costs and profitability have been conducted [16] and also the effects of global warming on ammonia and odour emissions have been analysed in recent studies $[17,18]$. However, the repercussions of global warming on environmental impacts and in particular on GHG emissions of confined livestock production systems are hardly addressed in the literature. Feed intake and energy demand for ventilation, heating and cooling in 
confined housing systems are highly dependent on temperature. Moreover, those inputs strongly contribute to the environmental impact of livestock production: life cycle assessments (LCA) found that the highest contribution to the environmental impact of pig production originates from feed supply, followed by on-farm energy inputs and on-farm animal- and manure-related emissions [19]. LCA is a well-recognised method for the holistic assessment of environmental impacts, which has already been applied to a variety of pig production systems, see e.g., a review article [20] or specific case studies, e.g., [19,21-25]. However, climate change adaptation has hardly been addressed.

Therefore, the present study will focus on the effect of increased ambient temperatures on the performance of confined pigs. Furthermore, the effect of global warming on inputs for pig production, i.e., feed requirements or energy demand per quantity of product, will be analysed. Accordingly, the LCA reveals the environmental impact of pig production with rising temperatures. LCAs are not sensitive to adaptation options, which do not directly affect animal performance, resource use or emissions from pig housing systems. This will be covered by a semi-quantitative system analysis, which identifies important factors for a comprehensive climate resilience of pig farms.

Four hypotheses are tested: (1) An increasing temperature such as expected until 2100 does not significantly decline important performance traits including mortality in temperate zones in confined housing systems. (2) Rising temperatures will not significantly increase inputs, i.e., feed and on-farm energy requirements per unit of product. (3) The environmental impact of pig production regarding energy use and emissions of greenhouse gases, acidifying and eutrophic substances (see definition in Section 2.2) does not significantly increase with global warming. (4) Effects of climate change other than those directly related to the performance of pigs, e.g., temperature increase and reduced precipitation in feed production, show a high impact on pig production systems (see Sections 2.3, 3.3 and 4.3).

\section{Materials and Methods}

\subsection{Model Calculations for Livestock Response to Temperature and THI Levels}

To test the hypotheses above, different methods were combined. An indoor climate simulation model reveals indoor climate parameters for various adaptation options [15]. Livestock responses were modelled based on data from various literature sources and were used in order to (i) derive basic functions for important production traits for confined pigs (i.e., body mass gain, feed intake, feed conversion and mortality), and (ii) for characterising pigs' response to increasing temperature.

For the analysis of the basic functions for important production traits, the literature sources and model assumptions shown in Table S1 in the Supplementary Material were used. Gompertz functions, linear and polynomic functions were derived from the sources listed in Table S1. Feed conversion was described by combining results from functions for feed intake and for body mass gain. All basic functions represent traits achieved under good environmental and hygienic conditions, i.e., among others, in absence of heat stress.

Available data from the scientific literature were used to determine the effects of an increasing indoor temperature, mainly data measured in feeding trials with controlled thermal environments (climate chambers; see Table S2 in the Supplementary Material for references). Responses to heat stress of feed conversion ratio, feed intake, body mass (gain) and mortality were derived for temperature alone and for a temperature humidity index (THI) specifically for the pig-categories sows, piglets, growing pigs and finishing pigs. Only few studies provide responses on humidity (plus temperature, feeding and performance data); hence, the results presented herein mainly focus on increasing temperature and correlated change of performance. For analysis of the THI effect, the THI-model according to National Weather Service Central Region [26] was used, which has also been used in other studies for pigs $[27,28]$ :

$$
\mathrm{THI}=((1.8 \mathrm{~T})+32)-(0.55 *(\mathrm{RH} / 100)) *(((1.8 \mathrm{~T})+32)-58)
$$


T is the ambient temperature in ${ }^{\circ} \mathrm{C}$ and $\mathrm{RH}$ the relative humidity, ranging from 0 to 100 and divided by 100 to be expressed in percent. To test differences between performance at normal temperatures (THIs) vs. those under heat stress conditions, a two-sample $t$-test was used; level of significance was set at $p \leq 0.05$.

Furthermore, worst case heat stress responses were identified from single studies: parameters (e.g., feed intake) from [29] for finishers and from [30] for growing pigs were included in a scenario "worst case situation", which simulates a temperature increase by $4.5^{\circ} \mathrm{C}$ indoors for a period from March to October.

The proportion of time spent under heat stress in a confined pig house (indoor climate) was derived from the indoor climate simulation model presented in [15]. It is based on hourly meteorological data between 1981 and 2017 and considers thermal properties of the building, the energy release of the pigs as well as the ventilation system. The data were calculated for a site north of the Austrian Alps, which is representative for confined livestock houses. The altitude of the province in Upper Austria is around $300 \mathrm{~m}$ above sea level, the average annual precipitation in the period 1971 to 2000 amounts to $980 \mathrm{~mm}$ and the average mean annual temperature is $8.8^{\circ} \mathrm{C}$ [31]. According to the climate classification of Köppen and Geiger, the site is classified as "warm temperature, fully humid, warm summers $(\mathrm{Cfb})^{\prime \prime}[32]$. Accordingly, the site is representative for large areas in Central Europe excluding the Alps [15]. Additionally, the site is highly representative for intensive pig production, as it represents the highest class of pig density with $>250$ pigs per $\mathrm{km}^{2}$ [5].

The outdoor and indoor temperatures-the latter for typical houses with mechanical ventilation systems-and proportions of time spent under heat stress (times above critical temperatures) were calculated for the period 1981 to 2010. A comparison between the coldest year in this period (1984) and the warmest year (2003) shows that mean outdoor temperatures differ by $1.5^{\circ} \mathrm{C}\left(8.2 \mathrm{vs} .9 .7^{\circ} \mathrm{C}\right)$, while the mean indoor temperatures differ by $1.0^{\circ} \mathrm{C}\left(18.4\right.$ vs. $\left.19.4{ }^{\circ} \mathrm{C}\right)$. The comparison of the heat stress potentials of these two years 1984 and 2003 is thus well suited to illustrate an effect of increased global temperatures by $1.5^{\circ} \mathrm{C}$ until 2100 following the low emission scenario [4].

For the heat stress effect on animal performance and on LCA impacts of pig production, proportions of the total annual time with occurrence of heat stress and with exceedance of the temperature limits were analysed. The indoor climate conditions were calculated for the housing systems without any technical changes over the time series. The following scenarios were compared for their heat stress effects:

- Cold year 1984

- Warm year 2003

- Hot year: 1984 plus $4.5^{\circ} \mathrm{C}$ (extrapolated "hot" year following IPCC [4])

- Worst case situation (see description above).

For further methodological and technical details concerning the housing system (completely confined, fully slatted floors) and its mechanical ventilation system, see [15].

\subsection{LCA Method: Impact Categories, System Boundaries and Inventories}

To assess the environmental impact of temperature increases on confined pigs, an LCA for the following impact indicators was used:

- Cumulative energy demand (CED; method v.1.10; in MJ)

- Global warming potential (GWP; in $\mathrm{CO}_{2}$ equivalents according to IPCC [4])

- Acidification potential (AP; CML-IA non-baseline V3.04/EU25; in $\mathrm{SO}_{2}$-eq)

- Eutrophication potential (EP; aggregating freshwater and marine eutrophication from the method ILCD 2011 Midpoint+ V1.10/EC-JRC Global, equal weighting; $\mathrm{N}$-eq and P-eq in $\mathrm{PO}_{4}{ }^{-}$-eq).

These environmental impact categories were identified as most important for pigs [20,22,23]. The assessment was conducted using SimaPro v8.5.0 and included provision of infrastructure. 
Using Monte-Carlo simulations in SimaPro v8.5.0, a probability distribution was generated with 10,000 iterations for every LCA result. This can be used to identify the uncertainty range of a result and to test differences between results for their significance.

As shown in Figure 1, the system boundaries for the inventory include material and energy inputs and emissions connected with livestock housing (manure management and enteric fermentation). Sow and piglet rearing were covered within the pig LCA. The main functional unit is $1 \mathrm{~kg}$ body mass of a finisher pig before slaughter, a further functional unit considered is $1 \mathrm{~kg}$ of reared piglet of $30 \mathrm{~kg}$ body mass at the farm gate.

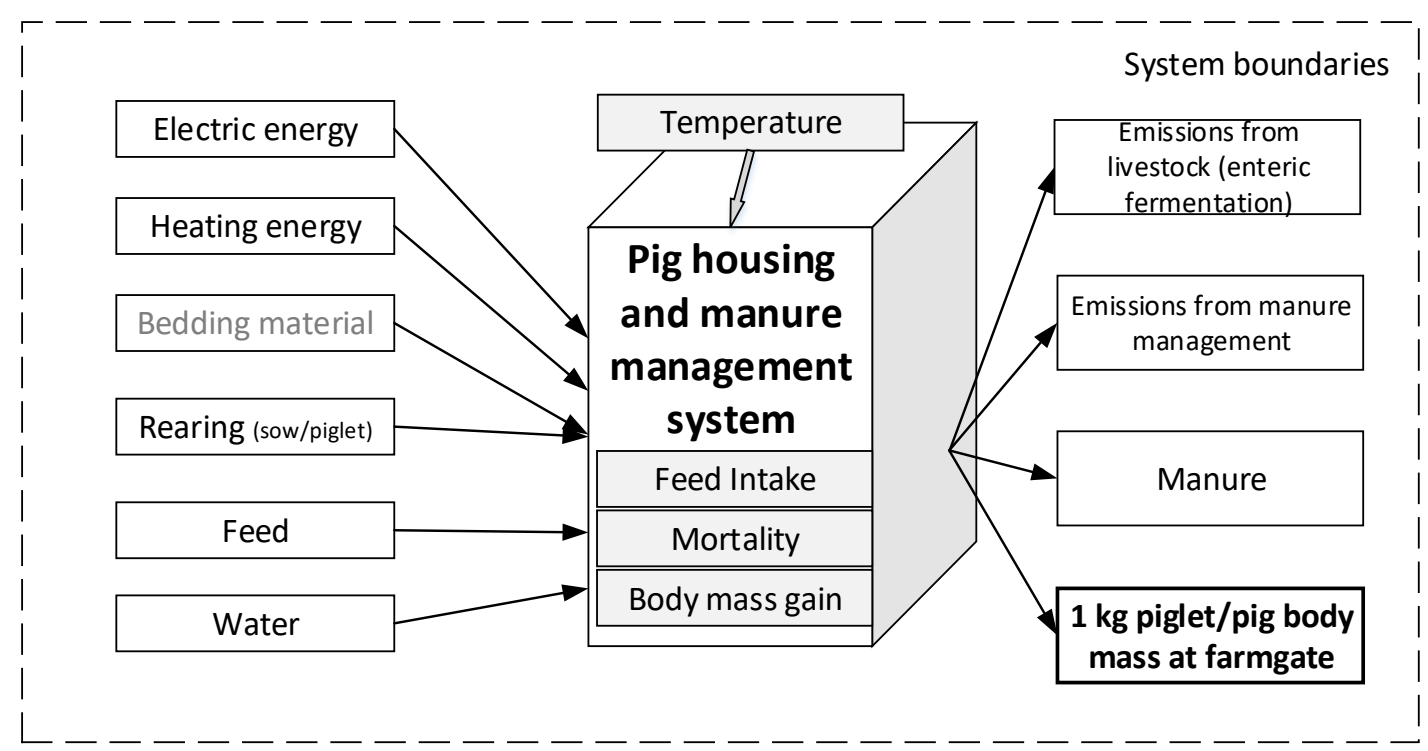

Figure 1. System boundaries for the pig production system with inputs and outputs and the effect of rising temperature on animal performance and environmental impact.

\subsubsection{Inventory Inputs}

Feed was identified as the most relevant input in the LCA studies mentioned above. The feed intake per kg body mass gain was calculated from equations in Table S1. For the feed ingredients, we used conventional default diets. The data for the average diet for sows (over the whole production cycle) including weaned piglets was derived from unpublished farm survey data and [33]; the average diet for growing-finishing pigs according to [34] can be seen in Table S3 in the Supplementary Material. The heat stress scenarios do not account for specific dietary modification as an attempt to reduce heat stress. Theoretical concepts exist for potential benefits of specific feeding strategies or single feeding measures for adapting to heat stress [35]. Some of these concepts are, however, questioned and generally applicable recommendations are lacking [36]. Therefore, dietary modifications are hardly implemented by pig producers in the analysed site.

Other major inputs in pig production besides feed are: (1) electric energy for feed and water supply, lighting, ventilation, cooling and heating systems, etc., which was assumed with the Austrian electric energy mix; (2) the operation of lorries and/or tractors for transports of feed, manure etc.; (3) water.

Table S4 in the Supplementary Material shows the quantities required per kg body mass gain and the sources used. Vaccinations and drugs were not accounted for in the inventory due to very low amounts applied and hence a very low influence on the impact categories addressed (CED, GWP, AP and EP). All environmental impacts related to energy and material inputs (e.g., feed) were calculated based on Ecoinvent data (v3.4) [37], following an attributional LCA approach.

In intensive livestock production systems, feed is frequently produced off-farm, purchased at international markets and imported into the system [5]. As a consequence, CCIs for feed crop 
cultivation are situated outside the system boundaries of the LCA; however, they are addressed in a semi-quantitative system analysis (see Sections 2.3 and 3.3).

\subsubsection{Inventory Outputs}

As shown in Figure 1, inputs and outputs were allocated to the functional unit of $1 \mathrm{~kg}$ piglet or $1 \mathrm{~kg}$ finished pig. Livestock produces manure, which replaces synthetic fertilisers for an integrated production of feedstuffs on-farm, and which contributes to undesired losses. The latter consist of ammonia $\left(\mathrm{NH}_{3}\right)$, nitrogen oxides $\left(\mathrm{NO}_{\mathrm{X}}\right)$ and dinitrous oxide $\left(\mathrm{N}_{2} \mathrm{O}\right)$ emissions arising from manure management. Furthermore, methane $\left(\mathrm{CH}_{4}\right)$ emissions result from both enteric fermentation and manure management.

For animal-related emissions, emission factors from [38,39] were utilised and typical slurry systems were assumed, with $50 \%$ of slurry stores being covered. The $\mathrm{CH}_{4}$ emissions were assumed to rise with increasing temperatures due to higher methane conversion factors [38]. $\mathrm{NH}_{3}$ emissions from housing and manure management systems were modified for high temperature according to [17]. The potential emissions for the low temperature scenario (based on the year 1984) are provided in Table S5 in the Supplementary Material.

Slurry-N (reduced for N-losses from manure management), $\mathrm{P}_{2} \mathrm{O}_{5}$ and $\mathrm{K}_{2} \mathrm{O}$ were accounted for as potential fertilisers that substitute a market mix of conventional mineral fertilisers according to [37]. For approximately $0.03 \mathrm{~kg} \mathrm{~N}$ per $\mathrm{kg}$ finishing pig body mass gain, a potential utilisation efficiency was assumed of $70 \%$ of the nitrogen applied. The amounts of $\mathrm{P}_{2} \mathrm{O}_{5}$ and $\mathrm{K}_{2} \mathrm{O}$ were assumed as $50 \%$ and $100 \%$, respectively, of those for $\mathrm{N}$.

\subsection{Semi-Quantitative System Analysis}

CCI effects on productivity parameters of the PS, which are in most cases outside the LCA system boundaries, e.g., CCI impacts on feed production, and interactions between PS elements, were estimated by a comprehensive system analysis. Besides the literature, e.g., [3,40,41], experts' knowledge was used for the system analysis, which was derived from a workshop with 13 experts and from additional interviews with selected experts.

First, system elements directly related to pig production (animals and housing) address parameters that could be affected by CCI or help to increase resilience against CCI. These are, for instance, health plans and measures to improve animal welfare, water supply of livestock, availability of affordable feed, feed losses, energy supply, access to CCI-related information and investments in CCI-relevant infrastructure. Second, other system elements for on-farm or off-farm feed production cover development of yields, locally adapted nutrient management, irrigation or landscape structures for greater biodiversity and more favorable conditions in terms of evaporation (hedges, trees, etc.). Third, further elements address soils or infrastructure, the type of tillage (e.g., conventional, conservation or reduced), the degree of using home-grown feed and feed storage capacities, farms' water and energy supply or a potential impact on the water supply of neighboring farms. Fourth, an additional group of system elements covers economic issues that may contribute to resilience: cooperation of farms, knowledge exchange or social networking.

Finally, 97 potential system elements were identified in literature and from experts for pig PS, including the upstream chains for e.g., feed. The whole system was divided into the two subsystems "Climate change impacts and feed crop production" and "Climate change impacts and livestock". The 13 and 12 most important system elements out of each approximately 50 elements were categorised to these subsystems, respectively (see Tables S6 and S7 in Supplementary Materials). The interaction of each factor with all other factors was evaluated by the experts within the two subsystems. The intensity of the relationship between elements varied from 0 , i.e., no or ambiguous impact, up to 2, i.e., a strong direct impact. These expert knowledge-based numbers were introduced into the software Systaim SystemQ $[42,43]$. By using this software, both the direct and indirect feedback loops between the 
system elements were evaluated. The results of the analysis quantify the contribution of each element to achieve a climate resilient pig production system.

\section{Results}

\subsection{Effects of Temperature Increase on Animal Performance}

Combining all literature data collected (Table S2), results for the TNZ and the upper critical temperatures were derived, e.g., $30^{\circ} \mathrm{C}$ for weaned piglets, $24{ }^{\circ} \mathrm{C}$ for finishing pigs and $20-22{ }^{\circ} \mathrm{C}$ for sows (Table S8). Above these upper limits of the TNZ, heat stress situations occur with significant effects on production traits. According to the literature analysed, upper temperature limits decrease with an increasing body mass of the pig. Hence, gradually decreasing upper limit values were used to derive heat stress impacts for growing pigs and finishing pigs (Table 1). No significant heat stress effects were detected on mortality rates of growing and finishing pigs and on fertility of sows. Generally, no heat stress effect was found for the performance of weaned piglets (Table 1). The example of the thermophilic piglets shows that animals at certain age and body mass (young and light-weight animals) are less affected by higher ambient temperatures than others. For lactating sows and their piglets, which are kept together in one housing system (mostly with separated areas), temperature demands diffe widely. While lactating sows require a temperature of about $20^{\circ} \mathrm{C}$, suckling piglets need temperatures around $29^{\circ} \mathrm{C}$ (Table S8). In sows, heat stress causes a decrease in milk yield and subsequently in piglet growth. With separate living areas for sows and piglets, the different requirements can be covered. Generally, the linear increments and reductions shown in Table 1 represent findings from trials, in which temperatures near hyperthermia were mostly not covered. Hence, our analysis showed that only under conditions of hyperthermia (i.e., substantially exceeding optimal temperatures), exponential relationships between temperature and, among other factors, feed conversion ratio (FCR) become apparent.

Table 1. Effects of heat sqtress on production traits.

\begin{tabular}{|c|c|c|c|c|}
\hline & $\begin{array}{c}\text { Significant Difference } \\
\text { between Thermoneutral } \\
\text { and Heat Stress Conditions }\end{array}$ & $\begin{array}{l}\text { Average Change Per } 1^{\circ} \mathrm{C} \\
\text { Temperature Change }\end{array}$ & $\begin{array}{l}\text { Average Change } \\
\text { Per } 1 \text { THI Unit }\end{array}$ & $\begin{array}{l}\text { Critical Temperatures for } \\
\text { a Beginning Heat Stress }\end{array}$ \\
\hline \multicolumn{5}{|c|}{ Growing pigs (30-60 kg body mass) } \\
\hline Body mass gain & yes & $-2.4 \%$ & $-2.2 \%$ & \multirow{3}{*}{$\begin{array}{l}\text { from } 25^{\circ} \mathrm{C} \text { to } 21.5^{\circ} \mathrm{C} \\
\text { (in steps of } 0.5^{\circ} \mathrm{C} \text { ) for } \\
\text { body mass from } 35 \text { to } \\
60 \mathrm{~kg} \text { (in steps of } 5 \mathrm{~kg} \text { ) }\end{array}$} \\
\hline Feed intake & yes & $-1.8 \%$ & $-1.6 \%$ & \\
\hline Feed conversion ratio & yes & $+0.6 \%$ & $+0.6 \%$ & \\
\hline \multicolumn{5}{|c|}{ Finishing pigs (>60 kg body mass) } \\
\hline Body mass gain & yes & $-4.2 \%$ & $-3.2 \%$ & \multirow{3}{*}{$\begin{array}{l}\text { from } 21.5^{\circ} \mathrm{C} \text { to } 20^{\circ} \mathrm{C} \\
\text { (in steps of } 0.107{ }^{\circ} \mathrm{C} \text { ) for } \\
\text { body masses from } 60 \text { to } \\
\geq 130 \mathrm{~kg} \text { (in steps of } 5 \mathrm{~kg} \text { ) }\end{array}$} \\
\hline Feed intake & yes & $-3.2 \%$ & $-2.3 \%$ & \\
\hline Feed conversion ratio & yes & $+1.1 \%$ & $+0.9 \%$ & \\
\hline \multicolumn{5}{|c|}{ Suckling piglets } \\
\hline Body mass gain & no & $-0.5 \%$ & $-0.5 \%$ & \multirow{4}{*}{$\begin{array}{l}30{ }^{\circ} \mathrm{C} \\
\text { No significant heat stress } \\
\text { effect for piglets derived } \\
\text { from literature }\end{array}$} \\
\hline Feed intake & no & $-1.0 \%$ & $-0.4 \%$ & \\
\hline Feed conversion ratio & no & $+0.5 \%$ & $+0.8 \%$ & \\
\hline Mortality & no & $-1.5 \%$ & $-1.6 \%$ & \\
\hline \multicolumn{5}{|c|}{ Sows } \\
\hline Conception rate & no (tending to significance) & $-0.8 \%$ & $1.0 \%$ & $23^{\circ} \mathrm{C}$ \\
\hline
\end{tabular}

Although a ventilation system was assumed to be in place, heat stress occurs on quite a remarkable proportion of days in the case study livestock building according to the results from the indoor climate simulation model (Table 2; only growing and fattening pigs are covered, which are the only animal categories showing a significant reaction to heat stress). Thereby, heat stress is assumed when the daily average temperatures exceed the upper limit of the TNZ (see Table 1). 
Table 2. Proportions of time with significant heat stress (related to temperature only) in the case study livestock building.

\begin{tabular}{|c|c|c|}
\hline & Growing Pig a & Finishing Pig ${ }^{b}$ \\
\hline \multicolumn{3}{|c|}{ Proportion of days exceeding the critical maximum temperature for heat stress (daily average basis) } \\
\hline Average period 1981-2010 & $13.1 \%$ & $27.9 \%$ \\
\hline Cold year (1984) & $6.3 \%$ & $19.9 \%$ \\
\hline Warm year (2003) & $21.9 \%$ & $34.8 \%$ \\
\hline $\begin{array}{l}\text { Scenario hot year ( } 1984 \text { plus } 4.5^{\circ} \mathrm{C} \text { increase of outdoor } \\
\text { temperature) }\end{array}$ & $27.4 \%$ & $44.1 \%$ \\
\hline $\begin{array}{l}\text { Scenario worst case year }\left(4.5^{\circ} \mathrm{C} \text { temperature increase indoor }\right. \\
\text { (based on 1984) for March to October) }\end{array}$ & $46.8 \%$ & $64.4 \%$ \\
\hline \multicolumn{3}{|c|}{ Difference between average temperature and critical maximum temperatures for proportion of days stated above $\left({ }^{\circ} \mathrm{C}\right.$} \\
\hline Average period 1981-2010 & 2.24 & 2.72 \\
\hline Cold year (1984) & 1.93 & 1.99 \\
\hline Warm year (2003) & 2.59 & 3.59 \\
\hline Scenario hot year $\left(1984+4.5^{\circ} \mathrm{C}\right.$ outdoor temperature $)$ & 2.40 & 3.41 \\
\hline $\begin{array}{l}\text { Scenario worst case year }\left(4.5^{\circ} \mathrm{C} \text { temperature increase indoor }\right. \\
\text { (based on 1984) for March to October) }\end{array}$ & 2.37 & 3.84 \\
\hline
\end{tabular}

$20.0^{\circ} \mathrm{C}$ according to body mass (from 60 to $130 \mathrm{~kg}$ ).

The results in Table S9 show that feed intake and feed conversion rates are affected by heat stress (related to temperature, not THI). Only significant effects (Table 1) were included here; for instance, a basal mortality of $2 \%$ for both weaned piglets and growing-finishing pigs and $15 \%$ for suckling piglets is included, but heat stress-related mortality increases are not included, as they are not significant according to the $t$-test of the literature data.

If housing systems are not equipped with adequate ventilation systems and thereby indoor temperature potentially increases by $4.5^{\circ} \mathrm{C}$ in comparison to a ventilated system (scenario worst case), heat stress becomes severe (Table 2) and also affects the FCR (Table 3). Still, the response of FCR to increasing temperatures shown in Table 1 is too little to cause significant differences in LCA results. For example, the difference for the FCR between the cold year 1984 and the simulated scenarios for the hot year scenario and the worst case year scenario are only $1.0 \%$ and $1.8 \%$, respectively (Table 3 ).

\subsection{Effects of Temperature Increase on Resource Use and Environmental Impacts}

Results for the GWP and the analysed temperature levels "cold" (based on year 1984), "warm" (year 2003), "hot" (based on year $1984+4.5^{\circ} \mathrm{C}$ increase outdoor) and "worst case" (based on indoor climate in the year $1984+4.5^{\circ} \mathrm{C}$ increase indoor) are presented in Figure 2 as well as in the Supplementary Information in Figure S1 (CED non-renewable), Figure S2 (CED renewable), Figure S3 (AP) and Figure S4 (EP). 
Table 3. Feed intake and feed conversion ratios as affected by heat stress and comparison to the year 1984 values.

\begin{tabular}{|c|c|c|c|}
\hline & Growing Pig ${ }^{a}$ & Finishing Pig $^{b}$ & Growing-Finishing Pig (Total) \\
\hline \multicolumn{4}{|c|}{ Feed intake $(\mathrm{kg})$} \\
\hline Period 1981-2010 & 78.0 & 204.4 & $282.4(100.3 \%)$ \\
\hline Year 1984 (cold) & 78.0 & 203.5 & $281.5(100.0 \%)$ \\
\hline Year 2003 (very warm) & 78.2 & 205.4 & $283.6(100.4 \%)$ \\
\hline $\begin{array}{l}\text { Extrapolated hot year }\left(1984+4.5^{\circ} \mathrm{C}\right. \\
\text { outdoor temperature) }\end{array}$ & 78.2 & 206.0 & $284.2(101.0 \%)$ \\
\hline $\begin{array}{l}\text { Worst case: } 4.5^{\circ} \mathrm{C} \text { temperature increase } \\
\text { indoor (based on 1984) for March to October }\end{array}$ & 78.4 & 208.2 & $286.6(101.8 \%)$ \\
\hline \multicolumn{4}{|c|}{ Feed conversion ratio FCR (kg feed $\mathrm{kg}^{-1}$ body mass gain) } \\
\hline Period 1981-2010 & 2.60 & 2.92 & $2.82(100.3 \%)$ \\
\hline Year 1984 (cold) & 2.60 & 2.91 & $2.82(100.0 \%)$ \\
\hline Year 2003 (very warm) & 2.61 & 2.93 & $2.84(100.4 \%)$ \\
\hline $\begin{array}{l}\text { Extrapolated hot year }\left(1984+4.5^{\circ} \mathrm{C}\right. \\
\text { outdoor temperature })\end{array}$ & 2.61 & 2.94 & $2.84(101.0 \%)$ \\
\hline $\begin{array}{l}\text { Worst case: } 4.5^{\circ} \mathrm{C} \text { temperature increase } \\
\text { indoor (based on 1984) for October } \\
\text { to October }\end{array}$ & 2.61 & 2.97 & $2.87(101.8 \%)$ \\
\hline
\end{tabular}

${ }^{a}$ with heat stress from $25^{\circ} \mathrm{C}$ to $21.5^{\circ} \mathrm{C}$ according to body mass (from 35 to $60 \mathrm{~kg}$ ). ${ }^{\mathrm{b}}$ with heat stress from $21.5^{\circ} \mathrm{C}$ to $20.0^{\circ} \mathrm{C}$ according to body mass (from 60 to $130 \mathrm{~kg}$ ).

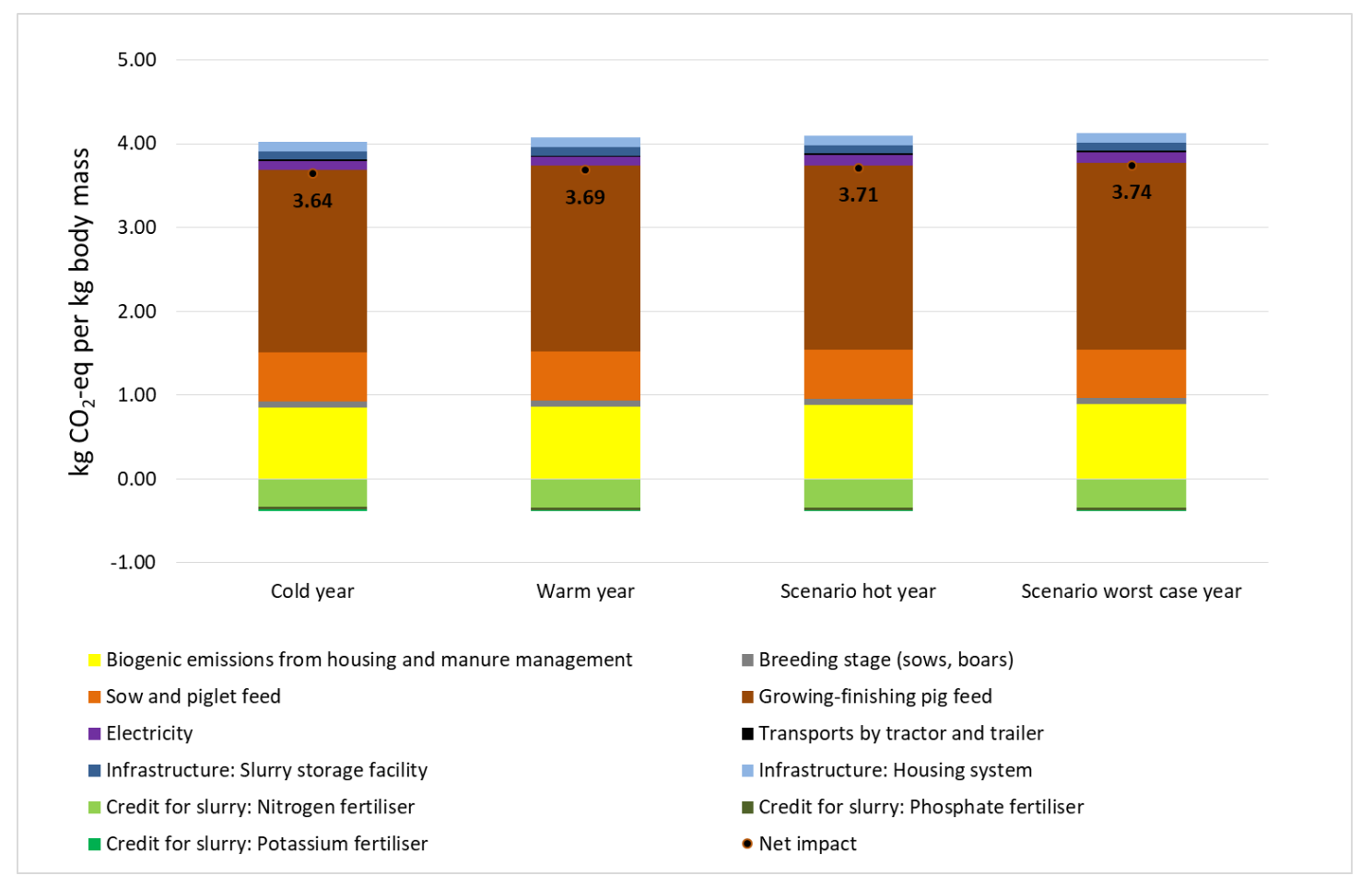

Figure 2. Average annual global warming potential (GWP) in $\mathrm{kg} \mathrm{CO}_{2}$-eq per $\mathrm{kg}$ body mass at farm-gate.

It is obvious that only very small differences were found between the temperature scenarios (years) for resource use and environmental impacts (Figure 2 and Figures S1-S4 in the Supplementary Material).

Significant differences in LCA results could not be identified except for one scenario comparison under special circumstances: if only the most extreme heat stress responses from [29,30] are used for finishers and growing pigs, the feed conversion and the GWP of the worst case scenario would 
increase by $12.2 \%$ and $21.3 \%$, respectively, for the comparison with the cold year (1984), (see Figure 3; Monte Carlo analysis with 10,000 runs). For all other comparisons with other temperature levels, the $95 \%$ confidence intervals in the Monte Carlo uncertainty analysis overlap very clearly. This is also a consequence of the fact that the uncertainties for many LCA emission factors and some input data (Ecoinvent) are generally high.

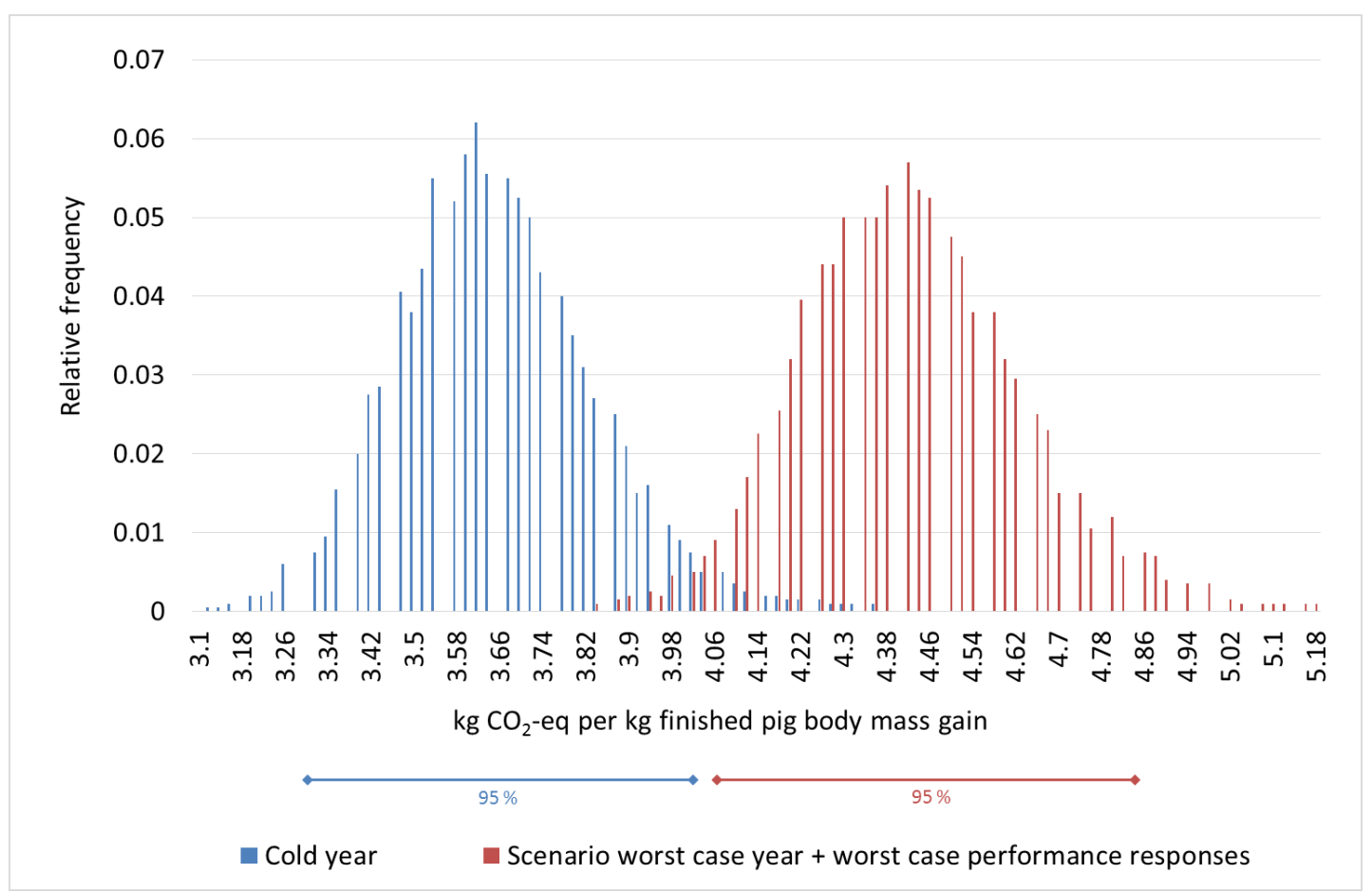

Figure 3. Results of the Monte Carlo analysis for the cold year 1984 and the "worst case scenario" with worst case-assumptions concerning heat stress responses (for $\mathrm{kg} \mathrm{CO}_{2}$-eq per $\mathrm{kg}$ finished pig body mass gain).

\subsection{Effects of Temperature Increase on Pig Production Systems not Directly Covered in LCA}

With regard to feed production, a number of system elements were found to be particularly important for maintaining yields despite adverse abiotic and biotic consequences of climate change (Figure 4): the use of plants with an appropriate genetic potential is highly relevant. Furthermore, in the light of increasing competition for land, especially from construction and agro-energy businesses, securing the access to land for feed production at reasonable costs is essential.

Other important elements are an intensity of land utilisation for feed production that is adjusted to the local conditions and measures contributing to specific ecological and socio-economic resilience against CCI, see also [44]. These include the protection of biodiversity and soil, the diversification of products and income sources and the implementation of insurance options or investments in CCI-relevant farm infrastructure. Moreover, options such as the installation of water-saving irrigation systems as a buffer in dry years may be relevant for adapting to CCI.

Regarding pig production systems, the following factors were identified as particularly important for achieving an optimal productivity, a high animal welfare status and a favorable economic performance: securing a sufficient water supply (both in terms of quantity and quality) and the use of technical measures against the effects of high temperatures or THIs during summer in housing systems. Management measures such as the use of health plans and prophylaxis against diseases associated with CCI are potentially important. Other options that may be considered are long-term feed security and a high genetic potential of the animals regarding e.g., thermoregulation [11]. Technical options to maintain (electrical) energy supply, i.e., emergency power generators, are necessary, particularly for 
sows and finishing pigs (Figure 4; the eight presented measures account for $57 \%$ of the resilience of an optimal system).

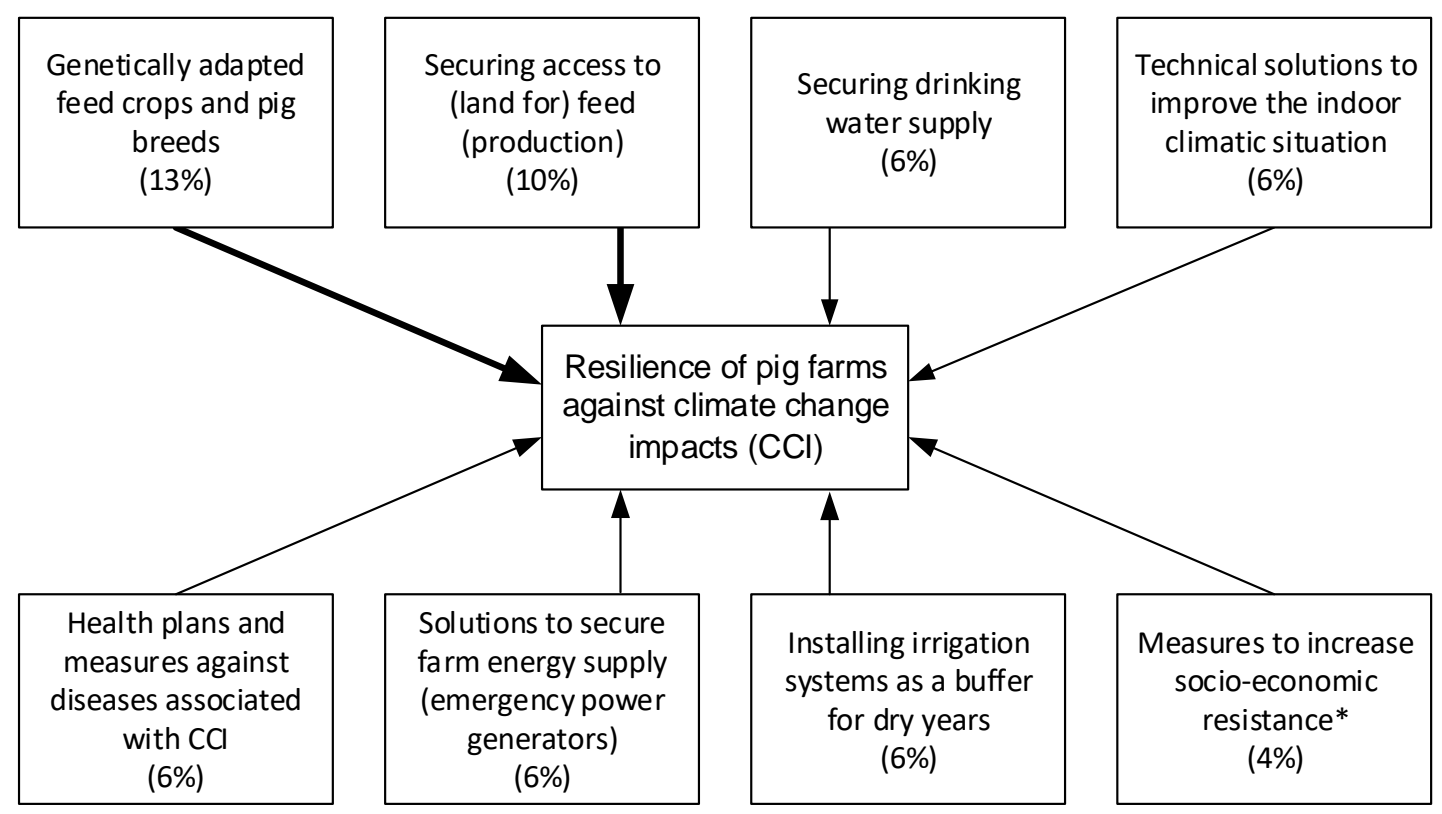

* e.g. diversification of products (income sources), use of insurance options and farm-cooperations, investment in CCl-relevant farm infrastructure

Figure 4. The most important system elements for climate resilience of pig farms and their specific impacts according to the semi-quantitative system analysis.

\section{Discussion}

\subsection{Practical Implications for Pig Production}

Despite the frequent occurrence of heat stress situations (Table 2), their impact on feed conversion seems very low (Table 3). Similarly, the increase in electric energy demand for ventilation systems appears negligible. This is mainly due to the low heat stress-related response in performance traits (Table 1). With the assumption of a properly working ventilation system and the usual thermal insulation, even a $4.5^{\circ} \mathrm{C}$ increase in outdoor temperatures does not lead to dramatic temperature changes inside the pig house $\left(+1.6^{\circ} \mathrm{C}\right)$, following the model described in [15]. In temperate zones, relatively low night temperatures (i.e., a low number of tropical nights) seem to keep the heat stress low. Longer heat stress phases would be physiologically more challenging than shorter phases which are interrupted by cooler phases, mostly during the night [45].

On the contrary, globally increasing temperatures during the winter months can reduce the need for heating, especially for piglets. However, typical (rather modern) housing systems with well running ventilation systems were assumed in the indoor climate simulation. Inadequate technical solutions for ventilation or thermal insulation would therefore result in higher average indoor temperatures and greater impacts on livestock.

Due to a remarkably better data availability for temperature- than for THI-related effects of heat stress, more robust estimates could be identified for temperature-related changes. Although some equations disproportionately increase THI in relation to the temperature [46], the indoor climate simulation performed in this study does not show a greater impact of a temperature-humidity increase on pig performance than a temperature increase alone (calculations based on Table 1 and the climate simulation model results according to [15]). 
The four hypotheses that were tested were confirmed: (1) Increasing temperatures do not significantly decline performance of pig production chains (including mortality), involving confined housing systems in temperate zones. (2) Requirements per product unit such as feed and electric energy will not significantly increase with rising temperatures; accordingly, (3) environmental impacts of pig production will not significantly rise with global warming. (4) CCI related to feed supply may have a greater impact on pig production systems and their output as well as environmental performance than those accounted for in the LCA. If there are no supra-regional feed production losses and if on-farm losses can be compensated for by purchases, insurances, etc., effects on LCA results will be relatively small.

The apparently small effects of climate change on mean annual pig performance and on environmental impact should not weaken efforts to reduce resource use, to mitigate environmental impacts and to adapt to CCIs. While, in the meta-analysis, no significant differences were detected for mortality from heat stress impacts, they are observed in practice $[47,48]$. The findings in this paper are based on system boundaries that include the entire production chain from reproduction and piglet rearing to the finisher pig, considering production of inputs, as it is typical for LCA studies. While heat stress is relevant mainly for the fattening-finishing phase, effects are not significant for sows and, contrarily, piglets need warm temperatures and are a heat-tolerant, even thermophilic animal category. If an LCA with narrow system boundaries would assess a farm that keeps fattening pigs only, a larger heat stress effect could be expected, especially for the summer months. Furthermore, LCA results are derived for annual averages (and not for warm seasons only). If differences between the climate scenarios for the combined life cycles breeding and growing-fattening are compared for the each of the summer months May, June, July, August and September, significantly higher CCI-induced LCA results are derived for half of all possible scenario comparisons.

Among other measures, dietary adaptation can contribute to cope with situations of a more severe heat stress of fattening pigs during summer months: in order to counteract a reduction in feed intake and performance, the dietary nutrient density should be adjusted [11]. Furthermore, a reduction in metabolic heat production can be achieved by increasing the dietary fat content and simultaneously reducing the carbohydrate and protein proportions, while maintaining the content of essential amino acids $[35,36,49,50]$. This was not accounted for in this study, but should be considered in future studies. Generally, pigs show a more sensitive genetically determined reaction to feeding than to heat stress [11].

According to [15], the mean annual trend for the occurrence of heat stress situations point to an increasing frequency of $+1.3 \%$ to $+5.8 \%$ per year for the three decades observed (1981-2010), relative to the reference year 1981. The authors conclude that adaptation measures are needed to mitigate this increase in heat stress situations and they emphasise its economic impact [15]. As decisions made by farmers are primarily driven by economic considerations, it is suggested to focus at the economic impacts of heat stress in future studies. In the context of a comprehensive sustainability assessment, however, ethical (e.g., animal welfare, resource use) and ecological aspects must not be left out. This paper aims at contributing to the latter.

\subsection{Limitations of the Method}

The small impact of heat stress on animal performance reported herein (Table 2) may be at least partially due to the methodological approach: all plausible heat stress impacts from the literature (Table 2) were combined into one dataset in order to derive the degree of change in FCR with an increase in temperature and THI in a simplified meta-analysis. The huge variation in response traits in the studies included obviously led to the relatively weak impact reported herein. Several individual studies reported a more pronounced effect of heat stress on the performance of pigs, e.g., [29,30]. Substantial differences in the conditions under which the different trials included in this analysis had been conducted (i.e., differing breeds, physiological stage, diets, trial factors such as the temperature pattern, duration of exposition, etc.) have blurred or even counteracted a pronounced effect. However, 
the conditions in the field vary as well and, hence, the results reported herein represent the average trend of expected effects.

A detailed analysis should specifically consider duration of individual heat stress phases; $24 \mathrm{~h}$ with heat stress within a $36 \mathrm{~h}$ period, but interrupted by cooler $12 \mathrm{~h}$ in between, are less problematic for the animals than a heat stress situation that lasts for $24 \mathrm{~h} \mathrm{[47].} \mathrm{In} \mathrm{the} \mathrm{performance} \mathrm{response} \mathrm{model,} \mathrm{every} \mathrm{day}$ with heat stress is equally accounted for, independent from the number of subsequent heat stress days. The reason for this limitation is that experimental data on livestock performance from the literature are not available, which would allow for an analysis of this relationship. Similarly, due to a lack of high resolution data, heat stress impacts could not be derived on an hourly basis in the performance response model, although data from the indoor climate simulation are available on an hourly basis. These limitations are likely to be one reason for the low heat stress impacts found herein.

\subsection{Implications from System Analysis}

Previous studies regarding CCI on livestock systems dealt primarily with pastoralists and smallholder farms in developing countries [40]. A comparison of the more vulnerable smallholder systems with the pig PS considered in this study helps to illustrate specifically important elements regarding climate resilience and thereby to highlight the most critical factors for potentially endangered PS. For instance, smallholder farms are usually not connected to supra-regional markets where they could purchase feed in order to counteract losses due to local droughts or floods, whereas most highly developed pig production systems are. In many of the global key regions of pig production, feed is only partially, if at all, grown on livestock farms. In some European countries such as Austria, however, a large proportion of the feed is cultivated on the pig producing farms [51]. Therefore, in the system analysis experts have assigned a high impact for resilience against climate change to "genetically adapted feed crops", "securing the access to land for feed production" and "irrigation systems". For a high climate-resilience, the combination of feed produced on the pig farm and a full access to feed markets seems optimal.

Additionally, pig producers in moderate climate with modern, fully confined systems frequently use insurance options for their crops and animals and thus are more resilient against CCI. Hansen et al. [52] pointed out that insurances, conservation agriculture practices, genetically adapted feed crops and diversified farming systems are the most important factors increasing resilience against CCIs. This is to a great extent in accordance with the results from system analysis of the present study (Figure 4).

\section{Conclusions}

For pigs in confined livestock houses in Central European countries, as represented by this Austrian case study, increasing temperatures do not significantly decline performance, do not increase input requirements per kg pig produced and do not significantly increase environmental impacts.

Pig farms which are resilient against climate change impacts and which mitigate environmental impacts can be characterised as follows:

(1) Pigs are kept in sufficiently thermally insulated housing systems that are at least mechanically ventilated. According to the results of this study and using a whole year perspective, air conditioning systems are not yet generally required. The environmental impacts do not increase significantly as a consequence of the predicted CCI. However, in order to prevent losses of fattening pigs and a reduced performance during the summer months, technical adaptations for improved indoor climate should be considered (e.g., pig showers for farms with sufficient water availability). As ventilation systems and other devices are dependent on electricity, a constant power supply must be ensured by an emergency power generator.

(2) Attention is paid to good animal performance in order to minimise resource consumption and environmental impacts. Thereby, the production systems contribute to climate change as little as possible, i.e., low greenhouse gas emissions. Potential impacts from CCIs are considered in the farm's breeding goals; for instance, cross breeding could be practiced with slower-growing 
animals that are more resistant against heat stress. A systematic observation of the animals and health plans are implemented against diseases in order to react to CCI.

(3) Attention is paid to the availability of inexpensive feed and of drinking water, especially for years with droughts, floods, storms and other CCI. Efficient on-farm production of feed, using crop varieties that are adapted to CCI, reduces feed costs when prices on the feed market increase as a consequence of specific CCI. If water is available, an irrigation system should be considered as a buffer for dry years. The integrated on-farm production of feed improves the efficiency of the nutrient cycle between livestock farming and crop production via manure and thus reduces resource requirements and related environmental impacts. Climate-resilient farms practice on an efficient use of water and feed without avoidable losses.

Supplementary Materials: The following are available online at http://www.mdpi.com/2071-1050/12/22/9442/s1, Table S1: Sources, model assumptions and parameters of functions for important production traits of confined pigs in temperate Western European agriculture, Table S2: List of literature sources defining temperature requirements, thermo-neutral zones, heat stress-temperatures and effects of increasing temperature on production traits, Table S3: Composition of the sow diet (average over the whole production cycle) plus piglet feed and the average growing-finishing pig diet in percent (on $88 \%$ dry matter basis), Table S4: Inputs other than feed and sources given as specific energy demand related to animal places or body mass, Table S5: Biogenic emissions ( $\mathrm{kg} / \mathrm{kg}$ body mass) as annual mean for the low temperature scenario for reared piglet and for growing-finishing pig (at farm-gate before slaughtering), Table S6: Elements related to climate change impacts in the feed production system, Table S7: Elements related to climate change impacts and livestock, Table S8: Thermoneutral zones (TNZ) of domesticated pigs $\left({ }^{\circ} \mathrm{C}\right)$, Figure S1: Use of fossil energy (CED non-renewable) in MJ per kg body mass at farm-gate, Figure S2: Use of renewable energy (CED renewable) in MJ per kg body mass at farm-gate, Figure S3: Acidification potential

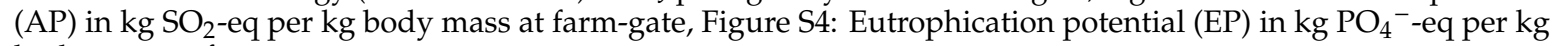
body mass at farm-gate.

Author Contributions: Conceptualization, methodology, software, validation, formal analysis, data curation, writing-original draft preparation, visualization: S.J.H.; Conceptualization, methodology, validation, writing-review and editing, supervision: W.Z.; writing-review and editing, project administration, funding acquisition: G.S.; software, resources, writing—review and editing: C.M.; writing-review and editing: I.H.-P., M.S., J.B., K.N., M.P., I.A. and K.A. All authors have read and agreed to the published version of the manuscript.

Funding: This publication within the project "PiPoCooL Climate change and future pig and poultry production: implications for animal health, welfare, performance, environment and economic consequences" was funded by the Austrian Climate and Energy Fund within the framework of the Austrian Climate Research Program (ACRP8-PiPoCooL-KR15AC8K12646).

Acknowledgments: The authors would like to thank Carina Keckeisen and Pauline Petring for their support in the PiPoCooL project. The authors also thank a number of anonymous reviewers for their helpful comments on earlier versions of this paper. The publication was supported by the BOKU Vienna Open Access Publishing Fund.

Conflicts of Interest: The authors declare no conflict of interest.

\section{References}

1. IPCC (Intergovernmental Panel on Climate Change). Climate Change 2013. The Physical Science Basis. Contribution of Working Group I to the Fifth Assessment Report of the Intergovernmental Panel on Climate Change; Stocker, T.F., Qin, D., Plattner, G.-K., Tignor, M., Allen, S.K., Boschung, J., Nauels, A., Xia, Y., Bex, V., Midgley, P.M., Eds.; Cambridge University Press: Cambridge, UK; New York, NY, USA, 2013; 1535p. Available online: https://www.ipcc.ch/site/assets/uploads/2018/02/WG1AR5_all_final.pdf (accessed on 13 July 2020).

2. Vermeulen, S.J.; Campbell, B.M.; Ingram, J.S.I. Climate Change and Food Systems. Annu. Rev. Environ. Resour. 2012, 37, 195-222. [CrossRef]

3. Gerber, P.J.; Steinfeld, H.; Henderson, B.; Mottet, A.; Opio, C.; Dijkman, J.; Falcucci, A.; Tempio, G. Tackling Climate Change through Livestock-A Global Assessment of Emissions and Mitigation Opportunities; FAO (Food and Agriculture Organization of the United Nations): Rome, Italy, 2013.

4. FAO (Food and Agriculture Organization of the United Nations). Strategy on Climate Change; FAO: Rome, Italy, 2017; Available online: http://www.fao.org/3/a-i7175e.pdf (accessed on 13 July 2020). 
5. Robinson, T.P.; William Wint, G.R.; Conchedda, G.; Van Boeckel, T.P.; Ercoli, V.; Palamara, E.; Cinardi, G.; D'Aietti, L.; Hay, S.I.; Gilbert, M. Mapping the global distribution of livestock. PLoS ONE 2014, 9, e96084. [CrossRef]

6. Vitt, R.; Weber, L.; Zollitsch, W.; Hörtenhuber, S.J.; Baumgartner, J.; Niebuhr, K.; Piringer, M.; Anders, I.; Andre, K.; Hennig-Pauka, I.; et al. Modelled performance of energy saving air treatment devices to mitigate heat stress for confined livestock buildings in Central Europe. Biosyst. Eng. 2017, 164, 85-97. [CrossRef]

7. Thornton, P.K. Livestock production: Recent trends, future prospects. Philos. Trans. R. Soc. B 2010, 365, 2853-2867. [CrossRef]

8. Bianca, W. The signifiance of meteorology in animal production. Int. J. Biometeorol. 1976, 20, $139-156$. [CrossRef]

9. Zumbach, B.; Misztal, I.; Tsuruta, S.; Sanchez, J.P.; Azain, M.; Herring, W.; Holl, J.; Long, T.; Culbertson, M. Genetic components of heat stress in finishing pigs: Development of a heat load function. J. Anim. Sci. 2008, 86, 2082-2088. [CrossRef]

10. Nardone, A.; Ronchi, B.; Lacetera, N.; Ranieri, M.S.; Bernabucci, U. Effects of climate changes on animal production and sustainability of livestock systems. Livest. Sci. 2010, 130, 57-69. [CrossRef]

11. Hoffmann, I. Climate change and the characterization, breeding and conservation of animal genetic resources. Anim. Genet. 2010, 41, 32-46. [CrossRef]

12. Johnson, J.S. Heat stress: Impact on livestock well-being and productivity and mitigation strategies to alleviate the negative effects. Anim. Prod. Sci. 2018, 58, 1404-1413. [CrossRef]

13. Hafez, E.S.E. Adaptation of Domestic Animals; Harcourt Publishers: Boston, MA, USA, 1968; p. 416.

14. Escarcha, J.; Lassa, J.; Zander, K. Livestock Under Climate Change: A Systematic Review of Impacts and Adaptation. Climate 2018, 6, 54. [CrossRef]

15. Mikovits, C.; Zollitsch, W.; Hörtenhuber, S.J.; Baumgartner, J.; Niebuhr, K.; Piringer, M.; Anders, I.; Andre, K.; Hennig-Pauka, I.; Schönhart, M.; et al. Impacts of global warming on confined livestock systems for growing-fattening pigs: Simulation of heat stress for 1981 to 2017 in Central Europe. Int. J. Biometeorol. 2019, 63, 221-230. [CrossRef]

16. St-Pierre, N.R.; Cobanov, B.; Schnitkey, G. Economic Losses from Heat Stress by US Livestock Industries. J. Dairy Sci. 2003, 86, E52-E77. [CrossRef]

17. Schauberger, G.; Piringer, M.; Mikovits, C.; Zollitsch, W.; Hörtenhuber, S.J.; Baumgartner, J.; Niebuhr, K.; Anders, I.; Andre, K.; Hennig-pauka, I.; et al. Impact of global warming on the odour and ammonia emissions of livestock buildings used for fattening pig. Biosyst. Eng. 2018, 175, 106-114. [CrossRef]

18. Piringer, M.; Knauder, W.; Anders, I.; Andre, K.; Zollitsch, W.; Hörtenhuber, S.J.; Baumgartner, J.; Niebuhr, K.; Hennig-Pauka, I.; Schönhart, M.; et al. Climate change impact on the dispersion of airborne emissions and the resulting separation distances to avoid odour annoyance. Atmos. Environ. X 2019, 2, 100021. [CrossRef]

19. Pelletier, N.; Lammers, P.; Stender, D.; Pirog, R. Life cycle assessment of high- and low-profitability commodity and deep-bedded niche swine production systems in the Upper Midwestern United States. Agric. Syst. 2010, 103, 599-608. [CrossRef]

20. de Vries, M.; de Boer, I.J.M. Comparing environmental impacts for livestock products: A review of life cycle assessments. Livest. Sci. 2010, 128, 1-11. [CrossRef]

21. Dalgaard, R.; Halberg, N.; Hermansen, J.E. Danish Pork Production-An Environmental Assessment; University of Aarhus: Tjele, Denmark, 2007; Volume 82.

22. Rudolph, G.; Hörtenhuber, S.; Bochicchio, D.; Butler, G.; Brandhofer, R.; Dippel, S.; Dourmad, J.Y.; Edwards, S.; Früh, B.; Meier, M.; et al. Effect of three husbandry systems on environmental impact of organic pigs. Sustainability 2018, 10, 3796. [CrossRef]

23. Dourmad, J.Y.; Ryschawy, J.; Trousson, T.; Bonneau, M.; Gonzàlez, J.; Houwers, H.W.J.; Hviid, M.; Zimmer, C.; Nguyen, T.L.T.; Morgensen, L. Evaluating environmental impacts of contrasting pig farming systems with life cycle assessment. Animal 2014. [CrossRef]

24. Dolman, M.A.; Vrolijk, H.C.J.; de Boer, I.J.M. Exploring variation in economic, environmental and societal performance among Dutch fattening pig farms. Livest. Sci. 2012, 149, 143-154. [CrossRef]

25. Basset-Mens, C.; van der Werf, H.M.G. Scenario-based environmental assessment of farming systems: The case of pig production in France. Agric. Ecosyst. Environ. 2005, 105, 127-144. [CrossRef]

26. National Weather Service Central Region (NWSCR). Livestock Hot Weather Stress; National Weather Service Central Region (NWSCR): Kansas City, MO, USA, 1976. 
27. Wegner, K.; Lambertz, C.; Daş, G.; Reiner, G.; Gauly, M. Climatic effects on sow fertility and piglet survival under influence of a moderate climate. Animal 2014. [CrossRef]

28. Wegner, K.; Lambertz, C.; Daş, G.; Reiner, G.; Gauly, M. Effects of temperature and temperature-humidity index on the reproductive performance of sows during summer months under a temperate climate. Anim. Sci.J. 2016. [CrossRef]

29. White, H.M.; Richert, B.T.; Schinckel, A.P.; Burgess, J.R.; Donkin, S.S.; Latour, M.A. Effects of temperature stress on growth performance and bacon quality in grow-finish pigs housed at two densities. J. Anim. Sci. 2008, 86, 1789-1798. [CrossRef]

30. Collin, A.; van Milgen, J.; Dubois, S.; Noblet, J. Effect of high temperature on feeding behaviour and heat production in group-housed young pigs. Br. J. Nutr. 2001, 86, 63. [CrossRef]

31. ZAMG (Zentralanstalt für Meteorologie und Geodynamik). Klimadaten von Österreich 1971-2000. 2002. Available online: http://www.zamg.ac.at/fix/klima/oe71-00/klima2000/klimadaten_oesterreich_1971_frame1.htm (accessed on 11 September 2020).

32. Kottek, M.; Grieser, J.; Beck, C.; Rudolf, B.; Rubel, F. World Map of the Köppen-Geiger climate classification updated. Meteorol. Z. 2006, 15, 259-263. [CrossRef]

33. LfL-Bayrische Landesanstalt für Landwirtschaft. Futterberechnung für Schweine. 2020. Available online: https://www.lfl.bayern.de/mam/cms07/publikationen/daten/informationen/futterberechnung_fuer_ schweine_lfl-information.pdf (accessed on 13 July 2020).

34. Schwarz, C.; Ebner, K.M.; Furtner, F.; Duller, S.; Wetscherek, W.; Wernert, W.; Kandler, W.; Schedle, K. Influence of high inorganic selenium and manganese diets for fattening pigs on oxidative stability and pork quality parameters. Animal 2017, 11, 345-353. [CrossRef]

35. Renaudeau, D.; Collin, A.; Yahav, S.; de Basilo, V.; Gourdine, J.L.; Collier, R.J. Adaptation to hot climate and strategies to alleviate heat stress in livestock production. Animal 2012, 6, 707-728. [CrossRef]

36. Mayorga, E.J.; Renaudeau, D.; Ramirez, B.C.; Ross, J.W.; Baumgard, L.H. Heat stress adaptations in pigs. Anim. Fron. 2019. [CrossRef]

37. Wernet, G.; Bauer, C.; Steubing, B.; Reinhard, J.; Moreno-Ruiz, E.; Weidema, B. The ecoinvent database version 3 (part I): Overview and methodology. Int. J. Life Cycle Assess. 2016, 21, 1218-1230. [CrossRef]

38. IPCC (Intergovernmental Panel on Climate Change). Chapter 10: Emissions from Livestock and Manure Management. 2006. Available online: https://www.ipcc-nggip.iges.or.jp/public/2006gl/pdf/4_Volume4/V4_ 10_Ch10_Livestock.pdf (accessed on 13 July 2020).

39. Amon, B.; Hutchings, N.; Dämmgen, U.; Webb, J. Manure Management. EMEP/EEA Air Pollutant Emission Inventory Guidebook 2016. Available online: https://www.eea.europa.eu/publications/emep-eea-guidebook-2016/part-bsectoral-guidance-chapters/4-agriculture/3-b-manure-management-2016 (accessed on 13 July 2020).

40. Choptiany, J.; Graub, B.; Philips, S.; Colozza, D.; Dixon, J. Self-evaluation and Holistic Assessment of Climate Resilience of Farmers and Pastoralists. Biodivers. Ecosyst. Serv. Agric. Prod. Syst. 2016, 166. [CrossRef]

41. FAO (Food and Agriculture Organization of the United Nations). Coping with Change Climate Change; FAO (Food and Agriculture Organization of the United Nations): Rome, Italy, 2015; ISBN 9789251084410.

42. Scholz, R.W.; Tietje, O. Embedded Case Study Methods. Integrating Quantitative and Qualitative Knowledge; Sage Publications: Thousand Oaks, CA, USA, 2002.

43. Tietje, O. Systemanalyse. In Qualitative Modellierung der Dynamik eines komplexen Systems; Systaim: Zürich, Switzerland, 2014.

44. Cabell, J.F.; Oelofse, M. An Indicator Framework for Assessing Agroecosystem Resilience. Ecol. Soc. 2012, 17, 1-13. [CrossRef]

45. Pearce, S. Evaluation of the Chronological Impact Heat Stress Has on Swine Intestinal Function and Integrity. Ph.D. Thesis, Iowa State University, Ames, IA, USA, 2014. Available online: https://ib.dr.iastate.edu/etd/14010 (accessed on 13 July 2020).

46. Walter, K.; Löpmeier, F.J. Fütterung und Haltung von Hochleistungskühen 5. Hochleistungskühe und Klimawandel. VTI Agric. For. Res. 2010, 60, 17-34.

47. Pig Site-Dealing with Drought and Evading Heat Stress in Swine. Available online: https://thepigsite.com/ articles/dealing-with-drought-and-evading-heat-stress-in-swine (accessed on 13 July 2020).

48. Myer, R.; Bucklin, R. Influence of Hot-Humid Environment on Growth Performance and Reproduction of Swine. 2001, pp. 1-6. Available online: https://edis.ifas.ufl.edu/pdffiles/AN/AN10700.pdf (accessed on 13 July 2020). 
49. Spencer, J.D.; Gaines, A.M.; Berg, E.P.; Allee, G.L. Diet modifications to improve finishing pig growth performance and pork quality attributes during periods of heat stress. J. Anim. Sci. 2005, 83, $243-254$. [CrossRef] [PubMed]

50. Black, J.L.; Mullan, B.P.; Lorschy, M.L.; Giles, L.R. Lactation in the sow during heat stress. Livest. Prod. Sci. 1993, 35, 153-170. [CrossRef]

51. BMNT (Bundesministerium für Nachhaltigkeit und Tourismus; Austrian Federal Ministry for Sustainability and Tourism; 2018) Grüner Bericht: Bericht über Die Situation der Österreichischen Land- und Forstwirtschaft. Available online: https:/gruenerbericht.at/cm4/jdownload/download/2-gr-bericht-terreich/1899-gb2018pdf (accessed on 13 July 2020).

52. Hansen, J.; Hellin, J.; Rosenstock, T.; Fisher, E.; Cairns, J.; Stirling, C.; Lamanna, C.; van Etten, J.; Rose, A.; Campbell, B. Climate risk management and rural poverty reduction. Agric. Syst. 2018. [CrossRef]

Publisher's Note: MDPI stays neutral with regard to jurisdictional claims in published maps and institutional affiliations.

(C) 2020 by the authors. Licensee MDPI, Basel, Switzerland. This article is an open access article distributed under the terms and conditions of the Creative Commons Attribution (CC BY) license (http://creativecommons.org/licenses/by/4.0/). 